\title{
Indicators and Methods for Assessing the Quality of Logistic Activity Processes
}

\author{
Submitted $30 / 08 / 19,1^{\text {st }}$ revision $28 / 09 / 19,2^{\text {nd }}$ revision $17 / 10 / 19$, accepted $25 / 11 / 19$
}

\section{Abstract:}

\author{
V.I. Gissin ${ }^{1}$, K.F. Mehantseva ${ }^{2}$, M.A. Surzhikov ${ }^{3}$
}

Purpose: This article is aimed at identifying and evaluating the quality and safety indicators of processes in the logistics system and solving the problems of product control in the goods' distribution process.

Design/Methodology/Approach: In order to assess the risks and quality of control methods in the goods' distribution processes, studies were carried out in the process of grain supply, on which the risk assessment was tested using the fault tree using a qualitative approach with a deductive logic, which allowed to identify events at the lower levels of the system. To evaluate the results when comparing various methods of monitoring the characteristics of products in the product distribution process certain statistical tools were used. The evaluation with comparative tests is required in order to determine the way of measuring products in the goods distribution logistics system. The study uses the methods of formalization, analysis, measurement, experimental and comparison.

Findings: The considered risk assessment method and the given example allow us to recommend its use for the product distribution processes for various purposes. A technique is proposed for comparing various control methods based on statistical tools that can be recommended for various goods' distribution operations.

Practical implications: The results of the study can be applied in practice to improve the quality of goods' distribution processes and reduce risks in the various supply chains.

Originality/value: The main contribution of this study is to shift the emphasis on the assessment of processes in goods' distribution to the positions of a risk-based approach and the use of various statistical tools in logistics' activities.

Keywords: Logistic system, assessment, quality, indicators, risks control methods.

JEL Code: M110.

Paper type: Research article: Quality Logistics.

\footnotetext{
${ }^{1}$ Professor, Department of Commodity Research and Quality Management, Rostov State University of Economics (RINH), Rostov-on-Don, E-mail: givi41@mail.ru

${ }^{2}$ Professor, Head of the Department of Commodity Science and Quality Management Rostov State Economic University (RINH), Rostov-on-Don, E-mail: mehantseva.karina@mail.ru ${ }^{3}$ Professor, Department of Personnel Management and Sociology, Rostov State University of Economics (RINH), Rostov-on-Don, E-mail: 2980135@mail.ru
} 


\section{Introduction}

When managing the processes of product distribution, the main attention should be paid to eliminating the causes leading to defects in the system, as well as moving products by changing the output parameters of the process. For this purpose, in the processes of logistic activity, it is necessary to determine control points with a set of process indicators, collect statistical information at the output of each control point and, based on the analysis of statistical data collected for a certain period of work, take corrective measures aimed at improving the processes of distribution. An analysis of the algorithms for the deliveries of products and raw materials shows that it consists of various processes, which, along with control operations, include a set of basic and auxiliary operations accompanying the vital stages of goods delivery. Such a process can be evaluated both by individual operations and by the general state of the quality of the process (the number of defects in the delivered products, the number of consumer complaints, etc.).

Each of the processes in the logistics system carries certain risks, which can be associated not only with the security of supplies, transported products, but also with the integrity and security of supply chains that may arise during transport operations. To improve the quality and safety of production processes and distribution, it is recommended to use risk-based thinking, the foundations of which are laid down in the standard document GOST R ISO 9001-2015 (2015).

When delivering products for various purposes (food, non-food products), questions may arise related to the choice of control methods or measuring instruments that can accelerate the time of process control, for example, unloading or loading products onto a vehicle. The use of new measuring instruments or methods requires a comparative analysis using statistical tools to assess the consistency of results. The presented work is aimed at identifying indicators that raise security processes in the logistics system and solving the problems of product control in the goods distribution process.

\section{Literature Review}

Recently, much attention has been paid to the quality and safety of processes in logistics systems, which cover various areas of activity, from production to storage and distribution processes.

In order to ensure a normal level of security and protect the integrity of the supply chain, a series of standards have been adopted in recent years (Supply Chain Security Management System 2005, 2006, 2018), which allow making informed decisions to prevent threats and reduce risks. In a number of works, process safety (Pogrebnaya, 2019) is considered from the standpoint of transportation safety, which is defined as the absence of adverse events, according to formula 1 : 
transport safety $=\frac{\text { total number of flights }- \text { number of accidents }}{\text { total number of flights }}$

The proximity of this indicator to unity indicates a high level of security. The analysis of recommended indicators, methods for evaluating supply processes in the logistics system, shows that many authors consider mainly such characteristics as: quality, reliability, flexibility, etc.

Pogrebnaya (2019) considers the cause-effect relationships of indicators that affect the quality of functioning of the supply chain processes, among the main indicators making a distinction as follows:

— reliability;

— supply chain flexibility;

— supply chain cycle length;

- costs;

— efficient use of fixed and working capital of the supply chain.

The listed indicators highlighted by the author are measurable and characterized by a set of specific metrics. Considering the flexibility of the supply chain, the author (Pogrebnaya, 2019) draws attention to metrics characterizing the flexibility of the supply chain, the indicators of which include: the speed of reaction to consumer orders, high optimal stock levels and the presence of distribution centers near customers.

Of great importance on the efficiency of the processes in the logistics system is reliability, which Gissin (2000) described as the "foundation of quality." The reliability of the supply chain gives an idea of the readiness of the supply process to uninterruptedly perform its functions while maintaining the specified characteristics (Gissin, 2017). Polubotko and Gissin (2007) came to the same conclusion when considering the reliability of supplies in the electric power system from the standpoint of uninterrupted operation. Reliability, according to these authors, includes the following indicators: product quality that meets the requirements of scientific and technical documentation, the required quantity of goods that meets the conditions of the supply contract, delivery on time and completed order execution.

Vasiliev and Gissin (2017) using statistical control tools when analyzing the supply of products for various purposes, concluded that it is possible not only to identify inconsistencies, but also to apply the necessary corrective actions that improve the supply processes. These authors have used statistical control tools when analyzing the supply of products for various purposes and concluded that it is possible not only to identify inconsistencies, but also to apply the necessary corrective actions that improve the supply processes. 
Studies conducted by the same authors on a large amount of information (Vasiliev and Gissin, 2018) showed that the use of control measures to improve the supply system of goods leads to an increase in the reliability of the system, in which defects in the supply of products can theoretically occur no earlier than "..once in a week compared to the existing frequency of failures that occur every two days." The calculation method proposed by the authors (Vasiliev and Gissin, 2018) allows us to determine and compare the reliability of supplies from various suppliers, identify removable defects, and introduce corrective actions. Of great importance in the distribution process are stocks formed from inventory that should have an optimal level determined by the size of the order, which minimizes the total cost of maintaining and replenishing the stock for the improvement of which it is advisable to use statistical tools (Schreibfeder, 2016; Albekov et al., 2017).

Considering process indicators in the logistics system, it should be noted their variability due to varying degrees of risk, the level of which must be constantly monitored. Currently, various tools are used to assess the degree of risk. The most common ones can be distinguished as: The "bow-tie" method ("Risk management. Methods of risk assessment", 2011); Risk Matrix ("Risk Management. Risk Register", 2012); A risk assessment method based on the identification of potential failures ("Quality systems in the automotive industry. A method of analyzing the types and consequences of potential defects", 2001).

The method of analyzing the types and consequences of failures allows you to identify the types of failures, the process of their development and possible consequences. The provisions of this analysis enabled Datchenko (2015) to develop a risk assessment methodology in the logistics system of food product distribution, i.e., this method of risk assessment can be used in logistics processes for the movement of goods for various purposes.

\section{Methodology}

In the process of production and distribution of products, it is often necessary to evaluate its performance, regulated by standards, technical regulations, which can be evaluated using various methods, such as organoleptic, instrumental, physic chemical.

In this study, we tested the risk assessment methodology recommended for use in the product distribution processes for the various purposes' products, conducted research on the evaluation of various measuring products methods in the product distribution process. Cereals were selected as the subject of research, which in the product distribution process should be controlled by such quality indicators as: nature, protein, gluten, drop number, moisture. Methods for evaluating indicators were carried out in accordance with the recommendations set out in the standards and the use of modern measuring instruments. Evaluation of the characteristics during comparative tests for the choice of methods of measuring products in the logistics system of goods 
distribution was carried out by the following methods: formalization, analysis, synthesis, abstraction, measurement, experimental, comparison.

\section{Research Results and Discussion}

It should be noted that in the analysis of the safety and reliability of various systems, along with the analysis of the types and consequences of failures, failure tree analysis (FTA), which is useful as a tool to reduce the likelihood of unwanted events, can be used. Gissin et al. (2018) used the failure tree (FTA) when assessing the risks of grain crops deliveries, where based on FTA risks are determined at various stages of the goods' distribution process and necessary corrective measures are developed.

Thus, the risk assessment made it possible to establish the acceptability of the risk level and propose a plan of minimizing and corrective measures. Considering the supply of grain products, it should be noted that in some processes the risk occurrence probability may appear, leading to a violation of the supply conditions. The risk assessment method and an example of application considered in Gissin and Levitskaya (2018) make it possible to recommend its use for goods distribution processes for various products. It should be emphasized that one of the main quality characteristics is minimization of losses and the time spent from the beginning of the order to its execution, which is reflected in the overall order cycle. Thus, the less time will be spent on the processes in the transport and logistics system, the more effective will be its activity in the distribution processes (Gissin et al., 2018).

In the process of distribution of products for various purposes, questions may arise related to the choice of control methods or measuring instruments that will speed up the control time when unloading or loading products onto a vehicle. The use of new measuring instruments or methods requires a comparative analysis of using statistical tools to assess the consistency of results.

To evaluate the obtained measurement results, we used statistical tools (Glantz, 1993) and a scatter chart (Bland, 1986), which is a dispersion chart on which the average value of the two compared methods in one test is plotted along the $\mathrm{X}$ axis, and the difference between the values of one test on the Y axis. As an example, Table 1 shows the results of studies of the grain moisture indicator obtained by measurement according to the standard method and using a moisture analyzer. Measurements were taken at twenty-five consignees within two months. The correlation coefficient between measurements carried out in two ways when assessing grain moisture was 0.993. The values of the correlation coefficient for the compared estimation methods indicate a strong relationship between the measurement methods. Based on the results of the presented data (Table 1), a dispersion diagram of the comparison of the measurement results when assessing humidity was constructed (Figure 1). Figure 2 shows a dispersion chart of two methods for measuring wheat moisture, which has a positive trend. 
Table 1. The results of grain moisture measurements (Gissin et al., 2019)

\begin{tabular}{|c|c|c|c|c|}
\hline $\begin{array}{l}\text { Consignee } \\
\text { company }\end{array}$ & $\begin{array}{l}\text { Standard } \\
\text { method }\end{array}$ & $\begin{array}{l}\text { Express - analysis } \\
\text { (moisture } \\
\text { analyzer) }\end{array}$ & $\begin{array}{l}\text { Difference of } \\
\text { indicators }\end{array}$ & $\begin{array}{l}\text { Average } \\
\text { value }\end{array}$ \\
\hline 1 & 12.3 & 12.5 & -0.2 & 12.4 \\
\hline 2 & 10.0 & 9.6 & 0.4 & 9.80 \\
\hline 3 & 14,8 & 14.6 & 0.2 & 14.70 \\
\hline 4 & 13.0 & 13.5 & -0.5 & 13.25 \\
\hline 5 & 13.9 & 13.9 & 0 & 13.90 \\
\hline 6 & 11.3 & 11.2 & 0.1 & 11.25 \\
\hline 7 & 10.5 & 10.6 & -0.1 & 10.55 \\
\hline 8 & 9.6 & 9.4 & 0.2 & 9.50 \\
\hline 9 & 12.5 & 12.6 & -0.1 & 12.55 \\
\hline 10 & 12.0 & 12.0 & 0 & 12.00 \\
\hline 11 & 11.6 & 11.5 & 0,1 & 11.55 \\
\hline 12 & 11.0 & 11.0 & 0 & 11.00 \\
\hline 13 & 10.9 & 10.8 & 0.1 & 10.85 \\
\hline 14 & 13.5 & 13.5 & 0 & 13.50 \\
\hline 15 & 12.6 & 12.7 & -0.1 & 12.65 \\
\hline 16 & 12.3 & 12.6 & -0.3 & 12.45 \\
\hline 17 & 11.2 & 11.4 & -0.2 & 11.30 \\
\hline 18 & 11.6 & 11.6 & 0 & 11.60 \\
\hline 19 & 13.3 & 13.3 & 0 & 13.30 \\
\hline 20 & 13.1 & 13.0 & 0.1 & 13.05 \\
\hline 21 & 14.3 & 14.0 & 0.3 & 14.15 \\
\hline 22 & 10.6 & 10.9 & -0.3 & 10.75 \\
\hline 23 & 9.2 & 9.2 & 0 & 9.20 \\
\hline 24 & 15.0 & 15.0 & 0 & 15.00 \\
\hline 25 & 11.5 & 11.3 & 0.2 & 11.40 \\
\hline
\end{tabular}

Figure 1. Scattering diagram of two methods of measuring humidity (Gissin et al., 2019)

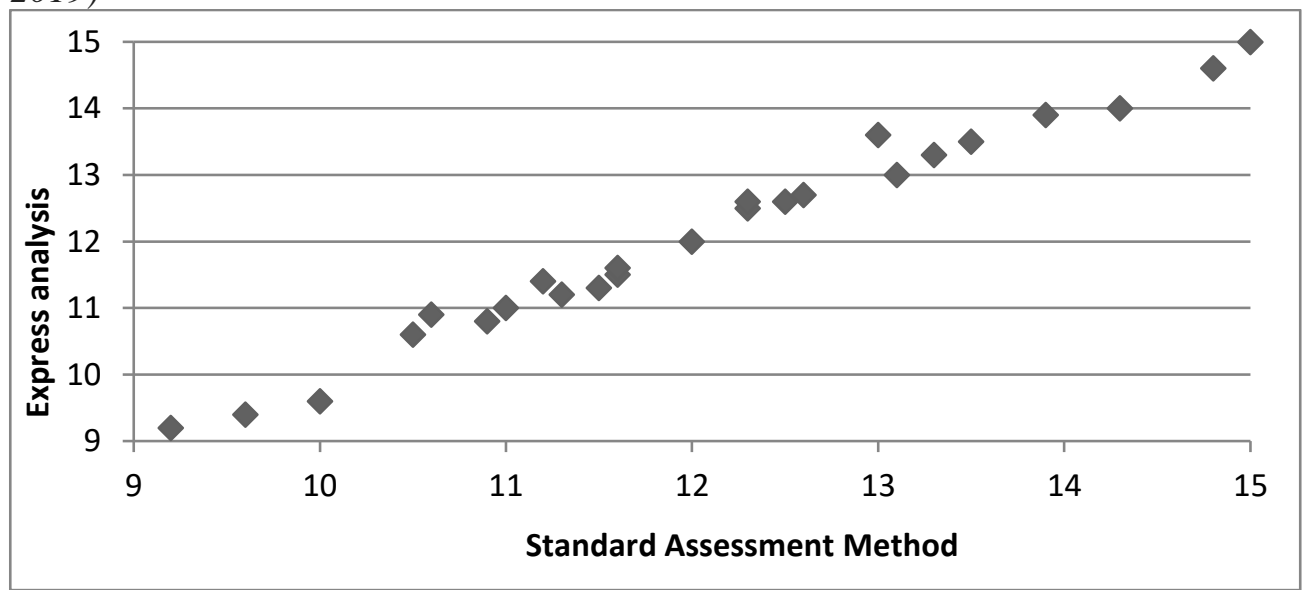


Figure 2. Scatter chart when comparing the results of assessing grain moisture (Gissin et al., 2019)

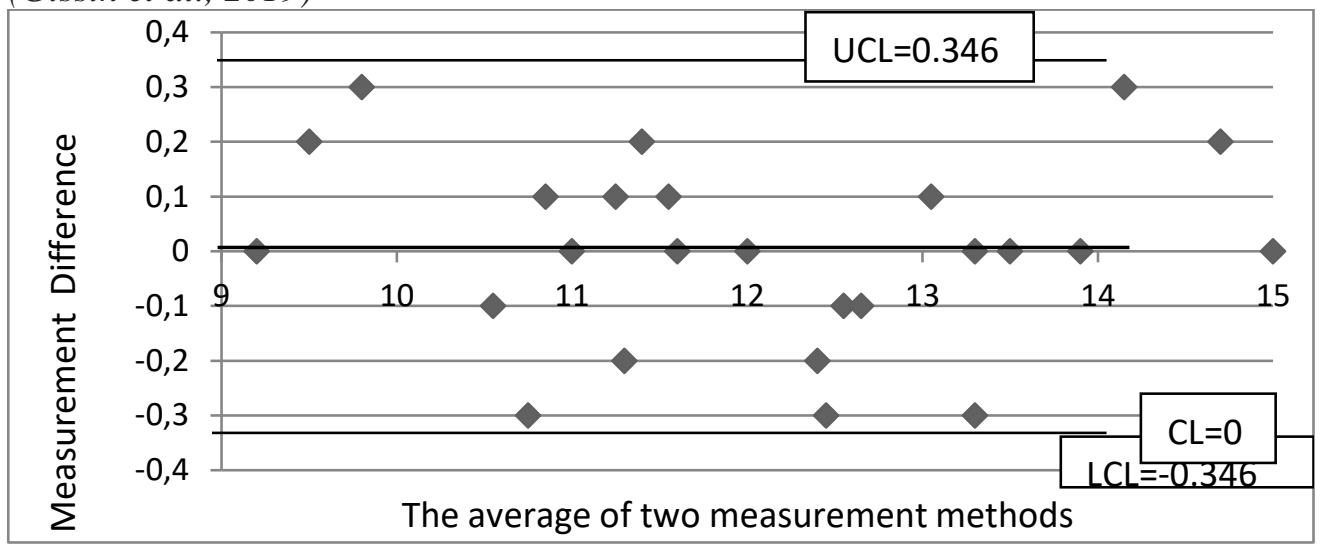

From the presented diagram the average difference between the measurements of grain moisture is zero. The standard deviations of humidity differences were 0.173 , which is small compared to the values of the coefficients.

\section{Conclusions}

When assessing the risks of deliveries of grain crops, it was proposed to use the Failure Tree (FTA), which will help to identify risks at various stages of the goods distribution process and develop the necessary corrective measures. When using the failure tree analysis, a qualitative approach was applied, using deductive logic, which made it possible to identify events at the lower levels of the system that could lead not only to a decrease in the grain class, but even to the customer's refusal to deliver.

The considered risk assessment method and the given example allow us to recommend its use for the processes of product distribution for various purposes. An analysis of the research results when assessing measurements of grain quality indicators in different ways showed high values of the correlation coefficient, indicating a close linear relationship. The obtained calculated average values for each estimation method indicate that the average difference between the measurements of grain moisture is zero. The standard deviations of humidity differences were 0.173 , which is small compared to the values of the coefficients.

Thus, the measurements obtained in two ways in assessing moisture are consistent with each other, therefore, the express method for assessing the moisture content of crops can be recommended for monitoring various operations of the goods distribution process. 


\section{References:}

Albekov, U.A., Parkhomenko, V.T., Polubotko, A.A. 2017. Green Logistics in Russia: The Phenomenon of Progress, Economic and Environmental Security. European Research Studies Journal, 20(1), 13-21.

Alizadeh, M., Amiri-Aref, M., Mustafee, N., Matilal, S. 2019. A robust stochastic Casualty Collection Points location problem. European Journal of Operational Research, 279, 965-983.

Altman, D.G., Bland, J.M. 1983. Measurement in Medicine: The Analysis of Method Comparison Studies. Statistician, 32, 307-317.

Altman, D.G., Bland, J.M. 1986. Statistical Methods for Assessing Agreement Between Two Measures of Clinical Measurement. Lancet, 1 (8476), 307-310.

Balteanu, A., Baldea, M., Gavriluta, A. 2018. Establishment of the Transport Route within an Internal and International Freight Transport Company. Supply Chain Management Journal, 1(9), 18-24.

Datchenko, A.A. 2015. Risk Assessment in the Logistic System of Food Product Distribution. Bulletin of the Rostov State University of Economics, 1(49), 25-31.

George, S., Weimerskirch, A 1985. Total Quality Management: Strategies and techniques Proven at Today's Most Successful Companies. Statistical quality control handbook. Western Electric Company, 385.

Gissin, V.I. 2000. Problems of Forming a Logistic System of Quality Management. Rostovon-Don, RSUE, 240.

Gissin, V.I., Levitskaya, A.S. 2018. Risk Assessment for Crop Supplies. Bulletin of the Rostov State University of Economics, 4(64), 87-91.

Gissin, V.I., Levitskaya, A.S., Surzhikov, M.A. 2019. Approaches to the Selection of Methods for Controlling the Quality of Goods in Transport and Logistics Processes. Bulleting of RSUE, 2(66), 26-36.

Gissin, V.I., Mehantseva, K.F. 2009. Updating the Methodological Foundations of Product Quality Management. Rostov-on-Don, Publishing and printing complex of SFEDU, 213.

Gissin, V.I., Mekhantseva, K.F., Putilina, T.I., Surzhikov, M.A. 2018. Green Economy: emerging national models, estimates and trends in the EU and the CIS. European Research Studies Journal, 21, Special Issue 1.

Gissin, V.I., Surzhikov, M.A. 2019. Method for Assessing Risks in the Processes of Product Distribution. The paradigmatic nature of fundamental and applied research, their genesis. Proceedings of the National Scientific and Practical Conference, St. Petersburg, March 29-30, 155-156.

Giustia, R., Manerba, D., Bruno, G., Tadeia, R. 2019. Synchro modal logistics: An overview of critical success factors, enabling technologies, and open research issues. Transportation Research, E129, 92-110.

Glantz, S.A. 1993. Primer of Biostatistics. McGraw-Hill, 459.

GOST R 51814.2-2001. 2001. Quality systems in the automotive industry. A method for analyzing the types and consequences of potential defects. Available online: http://vsegost.com/Catalog/29/2983.shtml.

GOST R 51901.23-2012. 2012. Risk management. Risk register. Guidance on risk assessment of hazardous events for inclusion in the risk register. Available online: http://docs.cntd.ru/document/1200100076.

GOST R 53661-2009 (ISO 28004: 2006). 2009. Supply Chain Security Management System. Implementation Guide. 
GOST R 53662-2009 (ISO 28001: 2006). 2009. Supply Chain Security Management System. Best practices for supply chain security, Estimates and plans.

GOST R 53663-2009 (ISO 28000: 2005). 2009. Supply Chain Security Management System. Requirements.

GOST R ISO / IEC 31010-2011. 2011. Risk Management. Methods of Risk Assessment. Available online: http://docs.cntd.ru/document/1200090083.

GOST R ISO 28004-3-2018. 2018. Supply Chain Security Management System. Guidelines for the Implementation of ISO 28000, Part 3, Additional special guidance on the implementation of ISO 28000 in organizations of medium and small businesses (except for seaports).

GOST R ISO 28004-4-2018. 2018. Supply Chain Security Management System. Guidelines for the implementation of ISO 28000, Part 4, Additional specific guidance on the implementation of ISO 28000 when compliance with ISO 28001 is the goal of management.

GOST R ISO 9001-2015. 2015. Quality Management Systems. Requirements.

Mekhantseva, K.F. 2011. Organization Quality and Sustainable Development Management Board: Statistical Model and it's Realization. Recent Economic Crisis and Future Development Tendencies. Proceedings of the 7th International Conference of Association of Economic Universities of South and Eastern Europe and the Black Sea Region (ASECU), Rostov State University of Economics, Rostov-on-Don, 540.

Mekhantseva, K.F. 2015. Modeling of the modern organization innovation and sustainable development on the base of the process approach. Proceedings of the $11^{\text {th }}$ international conference of ASECU "Openness, innovation, efficiency and democratization as preconditions for economic development", September 10-11, Krakow, Poland, 293-303.

Min, S.H., Zacharia, Z.G., Smith, C.D. 2019. Defining Supply Chain Management: In the Past, Present, and Future. Journal of Business Logistics, 40(1), 44-55, doi: 10.1111/jbl.12201.

Myrelid, P., Jonsson, P. 2019. Determinants of information quality in dyadic supply chain relationships. International Journal of Logistics Management, 1(30), 356-380, https://doi.org/10.1108/IJLM-12-2017-0343.

Partanen, J., Kohtamäki, M., Patel, P.C., Parida. V. 2019. Supply Chain Ambidexterity and Manufacturing SME Performance: The moderating roles of network capability and strategic information flow. International Journal of Production Economics, available online: https://www.sciencedirect.com/science/article/abs/pii/S0925527319302804.

Pogrebnaya, A.A. 2019. On the selection of measurable indicators for assessing the functioning of the supply chain. Logistics - Eurasian Bridge. Proceedings of the XIV International Scientific and Practical Conference, April 24-29, Krasnoyarsk, 255-258.

Pogrebnaya, A.A., Gissin, V.I. 2017. Performance indicators of food product distribution processes in the logistics system. Bulletin of the Rostov State University of Economics, 2(58), 49-55.

Polubotko, A.A., Gissin, V.I. 2007. On the issue of reliability of supplies in the electrical system. Market infrastructure: problems and prospects. Rostov-on-Don, RSUE, 266272.

Rampersad, H. 2001. Total Quality Management: An Executive Guide Continuous Improvement. Berlin, Heidelberg, Springer Verlag, 190.

Sajjanit, C., Rompho, N. 2019. Measuring customer-oriented product returns service performance. International Journal of Logistics Management, 3(30), 772-796. 
Schniederjans, D.G., Curado, C., Khalajhedayati, M. 2019. Supply chain digitization trends: An integration of knowledge management. International Journal of Production Economics, DOI: https://doi.org/10.1016/j.ijpe.2019.07.012.

Schreibfeder, J. 2016. Effective Inventory Management. Alpina Publisher, 304.

Somapa, S., Cools, M., Dullaert, W. 2018. Characterizing supply chain visibility: A literature review. International Journal of Logistics Management, 1(29), 308-339.

Starostka-Patyk, M. The Concept of Reverse Logistics in the Defective Products Management, the Theoretical Approach. Available online: https://drive.google.com/file/d/1rcRqBHGQ9SulLrwNcbGkch7rh_VbE1hj/view.

Vasiliev, V.P., Gissin, V.I. 2017. Methods for Assessing the Quality of the Supply Process. Innovation Achievements in Green Logistics: International Experience and Russian Practice. Proceedings of the XШ South Russian Logistics Forum, October 19-20, Rostov-on-Don, Publishing and printing complex RSUE, 229-232.

Vasiliev, V.P., Gissin, V.I. 2018. Managing the reliability of supply of low-alcohol products in the process of product distribution. Food Technology and Food Expertise.

Proceedings of the 3rd International Scientific and Practical Conference, April 5, Southwest State University, University Book CJSC, Kursk, 262. 